УДК 378

\title{
НЕКОТОРЫЕ АСПЕКТЫ ПРОФЕССИОНАЛЬНОГО СТАНОВЛЕНИЯ СТУДЕНТОВ ВУЗА В УСЛОВИЯХ РЕАЛИЗАЦИИ СОВРЕМЕННЫХ ОБРАЗОВАТЕЛЬНЫХ СТАНДАРТОВ
}

\author{
Белобородова Ниля Сабитовна \\ д.пед.наук, профессор \\ Кузнецова Инна Владимировна \\ к.пед.наук
}

ФГБОУ ВО «Башкирский государственный университет»

\begin{abstract}
Аннотация: В статье выявляются возможности профессионального саморазвития студентов в системе вузовского обучения в условиях реализации компетентностно-деятельностного подхода. Рассматривается сущность профессионального саморазвития студентов, его связь с понятиями профессионализма и компетентности. Определяются условия образовательноразвивающей среды, которая предполагает субъект-субъектное взаимодействие преподавателя и студентов, развитие субъектной позиции студентов, усиление роли активных методов обучения. Анализируются трудности в организации профессионального саморазвития студентов. Обосновываются этапы реализации профессионального саморазвития студентов с определением основных задач и средств для каждого этапа. Предлагаемая авторами система позволила стимулировать профессиональное саморазвитие и повысить уровень готовности студентов к его реализации.

Ключевые слова: профессиональное саморазвитие, барьеры профессионального саморазвития, развивающая образовательная среда, компетентностно-деятельностный подход.
\end{abstract}




\title{
SOME ASPECTS OF PROFESSIONAL DEVELOPMENT OF UNIVERSITY STUDENTS IN THE CONTEXT OF THE IMPLEMENTATION OF MODERN EDUCATIONAL STANDARDS
}

\section{Beloborodova Nilya Sabitovna Kuznetsova Inna Vladimirovna}

\begin{abstract}
The paper identified the possibility of professional self-development of students in university education in the conditions of realization of the competenceactive approach. The essence of professional self-development of students, its relationship to the concepts of professionalism and competence. The conditions of education and developing sre-dy, which implies a subject-subject interaction between teacher and students, develop-ment of a subject position of students, strengthening the role of active learning methods. The difficulties in the organization of professional self-development of students. Settle stages of professional selfdevelopment of students with key tasks and resources for each stage. The proposed system has allowed the authors to promote profes sional self-development, and improve the level of preparedness of students for its implementation.
\end{abstract}

Key words: professional self-development, the barriers of professional selfdevelopment, developing educational environment, competence-active approach

Модернизация образования требует усиления внимания к профессиональному саморазвитию студентов в процессе обучения в высших учебных заведениях. Развитие и реализация «человеческого капитала», способность к непрерывному личностному и профессиональному саморазвитию признаются многими учеными решающим условием модернизации экономики и общества в целом. Принятие Федеральных государственных образовательных стандартов более четко обозначили необходимость пересмотра традиционной парадигмы в системе вузовского обучения и приоритет новой, опирающейся на компетентностнодеятельностный подход. Главным критерием реализации данного подхода выступает не степень усвоения профессиональных знаний, а степень овладения компетенциями, которая характеризуется умением решать проблемы, возникающие в практической деятельности, самостоятельностью, творчеством студента как будущего специалиста своего дела. Способом формирования 


\section{ПЕРЕДОВОЕ РАЗВИТИЕ СОВРЕМЕННОЙ НАУКИ: ОПЫТ, ПРОБЛЕМЫ, ПРОГНОЗЫ}

требуемых компетенций становится специально организованная деятельность студента, имеющая свой состав, структуру и содержание, которая обеспечивает мотивационное поле, стимулирует потребность в самостоятельной деятельности и профессиональное саморазвитие. Сравнение возможностей традиционного подхода и компетентностно-деятельностного в обеспечении профессионального саморазвития студентов анализируются в статье [3, C. 5-11].

В ФГОС требования к результатам освоения основной образовательной программы находят отражение в компетенциях. В отличие от традиционных «ЗУНов» - знаний, умений и навыков, компетенции имеют комплексный характер и включают, кроме знаниевой компоненты, поведенческий аспект, то есть систему социальных, нравственных и профессиональных ориентиров, позволяющих выпускнику продуктивно строить профессиональную деятельность.

Исходя из сущности компетентности, следует, что в отличие от «знаниевого» опыта, она не существует заранее в готовом виде. Каждый субъект должен создать ее для себя заново, как продукт индивидуального творчества и саморазвития. В работах В. А. Болотова, В. В. Краевского, А. В. Хуторского и др. отмечается, что компетентность является следствием саморазвития индивида, его не столько технологического, сколько личностного роста, самоорганизации и обобщения деятельностного и личностного опыта [2, C. 7-12 ].

В тоже время, профессиональное саморазвитие рассматривается как процесс развития личности, ориентированный на высокий уровень профессионализма (Н.В. Кузьмина, А.К.Маркова и др.). Этот процесс для студентов обусловлен новыми целями и требованиями, которые возникают в соответствии с формированием представлений о профессиональной деятельности и профессиональной компетентности. Можно выделить наиболее значимые характеристики процесса профессионального саморазвития, отражающиеся в прогрессивных изменениях в структуре личности:

- актуализация мотивов профессиональных достижений;

- возрастание потребности в профессиональной самореализации;

- развитие профессиональных ценностей;

- развитие основ профессиональной рефлексии и профессионального самосознания;

- развитие профессионально значимых качеств; 


\section{ПЕРЕДОВОЕ РАЗВИТИЕ СОВРЕМЕННОЙ НАУКИ: ОПЫТ, ПРОБЛЕМЫ, ПРОГНОЗЫ}

- повышение профессиональной креативности личности;

- развитие акмеологических составляющих профессионализма;

- повышение практической готовности к профессиональной деятельности, в том числе в нестандартных ситуациях [4, с.60-62].

Понятия компетентности и профессионализма не всегда четко разграничиваются, нередко отождествляются, представляя собой характеристику личности специалиста. Под профессионализмом чаще всего понимают интегративное качество специалиста, указывающее на обладание им необходимыми для успешного выполнения трудовых функций в конкретном виде деятельности знаниями, навыками, умениями и другими личностнопсихологическими свойствами. Профессиональная компетентность определяется как качественная характеристика степени овладения будущим специалистом своей профессиональной деятельностью. Принципиальных различий в понимании рассматриваемых явлений нет [5, C.56-58].

Однако, например, в разработанной американской социальной наукой, модели «компетентного работника», получающей все большее внимание в мире, выделяется та часть индивидуально-психологических качеств специалиста, в которые входит самостоятельность, саморегулирование, самоанализ и стремление к саморазвитию. Среди основных характеристик компетентного человека выделяются следующие: 1) способность принимать решения относительно самого себя; 2) способность подавлять собственную неуверенность; 3) представление наиболее эффективных способов достижения цели; 4) способность определять характер и содержание деятельности в зависимости от складывающихся условий на основе имеющихся знаний и опыта; 5) способность к анализу собственной деятельности [1, С. 7-12]. Компетентностно-деятельностный подход требует переориентации на студентоцентрированный характер процесса профессиональной подготовки, что предполагает субъектно-субъектное взаимодействие, при котором студент в большей степени вовлечен в образовательный процесс, является активным субъектом собственного учения. Роль преподавателя становится направляющей на достижение конкретных целей и сопровождающей для приобретения определенных компетенций. Развиваясь как субъекты образования, студенты в большей степени осознают смысл и значение учебно-познавательной деятельности и будущей профессиональной деятельности, что стимулирует процессы саморазвития [6, С.15-17]. 


\section{ПЕРЕДОВОЕ РАЗВИТИЕ СОВРЕМЕННОЙ НАУКИ: ОПЫТ, ПРОБЛЕМЫ, ПРОГНОЗЫ}

Таким образом, система подготовки студентов, ориентированная на профессиональное саморазвитие, в процессе профессиональной подготовки на основе компететностно-деятельностного подхода показала возможность обеспечения достаточного уровня становления готовности к профессиональному саморазвитию студентов посредством осуществления соответствующего педагогического содействия со стороны преподавателя и поддержки субъектной позиции студентов.

\section{Список литература}

1. Андреев В.И. Педагогика высшей школы. Инновационнопрогностический курс: Учебное пособие [Текст] / В.И.Андреев. - Казань. Центр инновационных технологий, 2005. - 500 с.

2. Асадуллин Р.М. Реконструкция педагогического образования: соединение фундаментального и прикладного знания [Текст] // Педагогический журнал Башкортостана. - 2014. - № 2 (51). - С. 7-12

3. Белобородова Н.С., Черникова Т.А. Профессиональное саморазвитие будущих педагогов в контексте традиционного и компететностнодеятельностного подходов к обучению [Текст] // Пермский педагогический журнал. - 2014. - № 6. - С. 5-11

4. Бондаревская А.И. Культурно-образовательное пространство вуза как среда профессионально-личностного саморазвития студентов: автореф. дис.....канд. пед. наук [Текст] / Ростов-на-Дону: РГПУ, 2004. - 30с.

5. Зеер Э.Ф. Личностно-развивающие технологии начального профессионального образования.: учеб. пособие для студ. высш. учеб. заведений [Текст] / Э.Ф.Зеер. - М. : Издательский центр «Академия», 2010. C.56-58

6. Макарова, Л.Н. Технологии профессионально-творческого саморазвития учащихся [Текст] / Л.Н. Макарова, И.А. Шаршов. - М.: ТЦ Cфера, 2005. - 96 c.

(С) Н.С. Белобородова, И.В. Кузнецова, 2020 